\title{
Born to Rule: Burlamaqui and Rousseau on the Education of Princes
}

\author{
Lisa Broussois \\ 1 The Barbarous Philosopher: Rousseau's \\ Critique of the Education of Princes
}

The opening lines of Rousseau's Principles of the Right of War, probably mainly written in $1755^{-1756}$, $^{1}$ gave a radical critique of the literary world of the time. Rousseau denounced the gap he noticed between what was generally taught in books on law and ethics and the reality people had to face in their everyday lives. He began:

I open the books on right and on ethics; I listen to the scholars and jurisconsults and, moved by their ingratiating discourses, I deplore the miseries of nature, I admire the peace and justice established by the civil order, I bless the wisdom of public institutions, and console myself for being a man by seeing that I am a citizen. Fully instructed about my duties and happiness, I close the book, leave the class-room, and look around me $[\ldots]^{2}$

What did Rousseau see around him? The answer was clear: the huge gap between the scholars and jurisconsults' books and the real world. Nothing he had read in books could prepare him for facing the reality of his time. Rousseau used harsh words to describe it: misery, chaos, the more powerful with the laws on their side and the weakest being the unfortunate victims of an unjust system. The worst of all our destructive creations that he mentioned was war. War

1 See Blaise Bachofen and Céline Spector, 'Introduction: Jean-Jacques Rousseau, la guerre et la paix,' in Principes du droit de la guerre, Écrits sur la paix perpétuelle, ed. B. Bachofen and C. Spector (Paris: Vrin, 2008), 10.

2 Jean-Jacques Rousseau, 'The State of War,' in Rousseau, The Social Contract and other later political writings, ed. Victor Gourevitch (Cambridge: Cambridge University Press, 1997), 162. French edition: Jean-Jacques Rousseau, 'Principes du droit de la guerre,' in Principes du droit de la guerre, Écrits sur la paix perpétuelle, ed. Bachofen and Spector, 69 . 
everywhere - war, which was the product of public institutions, the product of existing policies. He expressed his indignation: 'So this is the fruit of these peaceful institutions! Pity, indignation swell up in the depths of my heart. Ah barbarous philosopher! Read us your book on a battlefield!3

Indignation and pity were the only possible emotional reactions for a man who had decided to face the truth that public institutions and civil order were far from guaranteeing peace and justice and there was no wisdom to be found in them at all. Rousseau believed that experience was a better means of education than books because books brought with them all the prejudices and the lies of their authors. Experience, at least, gave an opportunity to judge for oneself. Rousseau's idea of education was, firstly, to preserve and protect children from a culture that was harmful in order to have future individuals who were capable of judging for themselves. In Emile, his book on education, he insisted on this point: 'I do not tire of repeating it: put all the lessons of young people in actions rather than in speeches. Let them learn nothing in books which experience can teach them'. ${ }^{4}$ He believed that reading books led to a habit of taking for granted what other people believed or wanted their readers to believe. Instead of developing their own thinking, young people were, little by little, deprived of their natural sense of judgment and were not able to think autonomously anymore. He explained:

We are bent over books from our childhood and accustomed to read without thinking; what we read is all the less striking to us since we already contain within ourselves the passions and the prejudices which fill history and the lives of men, and therefore all [that] men do appears natural to us because we are outside of nature and judge others by ourselves. ${ }^{5}$

Teachers misled their pupils insofar as they filled the heads of young people with prejudices and made them become exactly like their educators. Rousseau pointed out that the teachers were, in general, not the best people to be taken as examples. Indeed, Rousseau believed that, unfortunately, philosophers writing on law and ethics not only created a gap between reality and their books, which were filled with prejudices, but also were ignorant of the very matter they were supposed to teach: 'It is not philosophers who know men best. They

3 Rousseau, 'The State of War,' 162. Rousseau, 'Principes du droit de la guerre,' 69.

4 Jean-Jacques Rousseau, Emile, or On Education (Hanover and London: University Press of New England, 2010), 408. French edition: Jean-Jacques Rousseau, Émile ou De l'éducation (Paris: Gallimard, 1969), 382.

5 Rousseau, Emile or on Education, 396. Rousseau, Émile ou De l'éducation, 368. 
see them only through the prejudices of philosophy, and I know of no station where one has so many' 6

His critique of those philosophers, writers of books on law and ethics, professors and jurists, went further. It was not just the gap between those books and reality that worried Rousseau, nor was it the ignorance of philosophers about what human beings were; it was also the support those philosophers gave to the political system, to the figure of the prince in monarchies who oppressed his subjects. Rousseau strongly condemned what he called the interested author, the one who wrote books only for her/his career and the advantage it could create for her/him, without caring about truth or authentic good and real justice. He observed:

The People grants neither pensions, nor positions, nor [University] chairs, nor memberships in Academies; why should it be protected? Magnanimous princes, I speak in the name of the literary establishment; oppress the people with a clear conscience; we expect everything from you alone; the people is no good to us. ${ }^{7}$

In Emile, he noticed how self-interested preceptors were and how bad was the result for the education of young people: 'A preceptor thinks of his own interest more than of his disciple's. He is devoted to proving that he is not wasting his time and that he is earning the money he is paid. He provides the child with some easily displayed attainments that can be showed off when wanted'. 8

The figure of the 'barbarous philosopher', eminent member of the literary establishment', was the exact opposite of what Rousseau aspired to be - to such an extent that he defined his own philosophical project in reaction to what these self-interested authors were doing. Rousseau's aim was to study human institutions and call them into question through study of their first principles and, above all, he wanted to correct the 'false ideas' that these self-interested authors supported. ${ }^{9}$ In the books of self-interested authors could be found, for example, the idea that the aim of the government was public felicity and that the administration was acting in the public interest. But in book III, chapter 6 of the Social Contract, 'Monarchy', Rousseau wrote the following: 'everything proceeds toward the same goal, it is true, but that goal is not public felicity, and the very force of the administration constantly works to the prejudice of

6 Rousseau, Emile, or On Education, 399. Rousseau, Émile ou De l'éducation, 371.

7 Rousseau, 'The State of War,' 162. Rousseau, 'Principes du droit de la guerre,' 69-70.

8 Rousseau, Emile, or On Education, 306-307. Rousseau, Émile ou De l'éducation, 260.

9 Rousseau, 'The State of War,' 163 . Rousseau, 'Principes du droit de la guerre,' 70. 
the State'. Did it serve to try to make people believe in lies? The truth was that princes acted in their own personal interest and did the contrary of what they should do in the public interest. ${ }^{10}$ Rousseau continued:

A political sermonizer may well tell them that since the people's force is their force, their greatest interest is to have the people flourishing, numerous, formidable; they know perfectly well that this is not true. [...] I admit that, assuming always perfectly submissive subjects, it would be in the Prince's interest that the people be powerful, so that this power, being his, might render him formidable to his neighbors $[\ldots] .^{11}$

Without doubt, a flourishing, numerous, and formidable people would be a great advantage for a prince, so that the state might be respected and feared, and might discourage attacks on its frontiers, but this would be the case only if the prince had 'perfectly submissive subjects'. Princes were well aware that it was never in their private interest to have powerful subjects. It was thus useless to continue telling a prince that he should act in the interest of his people. The prince's interest and the people's interest differed too much.

Let us take for example the book of reference in Europe at the time for the education of princes, François Fénelon's The Adventures of Telemachus. Fénelon's Mentor was among those who defended this pattern. He taught Telemachus that the wise king saw to it that his subjects should live in abundance and acted in the interest of their happiness. ${ }^{12}$ It is clear that Rousseau also had Hobbes in mind, as the Leviathan was presented as a manuscript to the future King Charles II when they were both in exile in Paris. Hobbes hoped that the Leviathan would instruct the prince in the best methods of ruling. He explained: 'Now in Monarchy, the private interest is the same with the publique. The riches, power, and honour of a Monarch arise onely from the riches, strength, and reputation of his Subjects. For no King can be rich, nor glorious,

10 The same severe statement can be found in Rousseau's Jugement sur la paix perpétuelle, in Principes du droit de la guerre, Écrits sur la paix perpétuelle, ed. Bachofen and Spector, 118. Rousseau explained that kings' actions pursued two goals: to spread their dominion beyond their country and to make their dominion more absolute within. Public felicity was a mere pretext.

11 Rousseau, Of the Social Contract, in The Social Contract and other later political writings, ed. Gourevitch, 95. French edition: Jean-Jacques Rousseau, Du contrat social (Paris: Flammarion, 2001), 106-107.

12 Fénelon, Telemachus, son of Ulysses, ed. and transl. Patrick Riley (Cambridge: Cambridge University Press, 1994), 16. Fénelon, Les aventures de Télémaque (Paris: Garnier, 1987), 137 . 
nor secure; whose Subjects are either poore, or contemptible, or too weak through want, or dissention, to maintain a war against their enemies.' ${ }^{13}$ But the truth for Rousseau was the opposite: private and public interests were never the same, at least in a monarchy. Princes knew it and so did their instructors.

If princes read books on law and ethics, as Rousseau did, they would also recognize quickly enough that these books described a different world from the one they lived in. These books told people what they were supposed to be and what they should do. However, the truth was, firstly, that princes considered themselves different from other people and, secondly, that they had never been used to listening and obeying. The reality of the army and the court invited them instead to behave quite differently from the way philosophers claimed they should. Instead of learning about their duties as princes and about their responsibilities, princes were encouraged to act as they wished, without any care for the consequences and, worst of all, self-interested authors defended them and pretended to be unaware of the reality that was right in front of their eyes.

Fénelon's Telemachus complained about the duplicity of a king's entourage and thought a monarch was lost if she/he could not resist flattery. ${ }^{14}$ But what happened in the real world? Princes were not morally good and not politically responsible. These latter remarks also showed why the figure of the prince was important and, at the same time, why the situation seemed so desperate to Rousseau, because the solution to human misery might lie in the prince's hands, but he was never up to the task. Rousseau was very pessimistic about the education of princes; indeed, in his view it was a complete failure. The problem was that the monarchic system was entirely corrupt. Even if the prince and the instructor had good intentions and wanted to make things right, there would still be the flattery of the court and the corruption of the army to spoil everything: "Everything conspires to deprive of justice and reason a man brought up to command others. Great pains are taken, so they say, to teach young Princes the art of ruling; it does not appear that this education profits them. It would be better to begin by teaching them the art of obeying'. ${ }^{15}$ Even if a prince was, in the future, destined to rule, a young prince was not yet a ruler. He was a child, not a monarch. Children were not just future adults; they were already people with their own needs and their own identities. Raising a child as a prince meant that there was confusion between what the child was

13 Thomas Hobbes, Leviathan, ed. Richard Tuck (Cambridge: Cambridge University Press, 1996), 131.

14 Fénelon, Telemachus, 20. Fénelon, Les aventures de Télémaque, 141.

15 Rousseau, Of the Social Contract, 97. Rousseau, Du contrat social, 110. 
and what he was supposed to become one day. Young princes were raised as if they were different from ordinary mortals: inevitably, the result was that they believed it and acted accordingly.

How could a prince be a good ruler if he was not able to put himself in the place of the people he commanded? Rousseau concluded by asking: 'and if a royal education necessarily corrupts those who receive it, what can be expected of a succession of men brought up to rule?'16 For Rousseau, selfinterested authors pretended to be unaware of how royal education corrupted young princes. They taught them only how to make speeches using virtuous and noble vocabulary, but this fooled no one: 'Our Authors have noticed these difficulties, but they have not been disturbed by them.'17

Unlike the 'literary establishment', Rousseau wanted to denounce these difficulties. This is probably one of the main reasons why Rousseau refused to advise the Swiss Reverdil to help the preceptor Reventlow in educating the future king Christian VII of Denmark. ${ }^{18}$ Rousseau's rejection of the education of princes may appear surprising at first sight, knowing that his major work, Emile, focused on education. However, in Emile, Rousseau expressed his views even more clearly, recounting, for example, the following anecdote:

Someone of whom I know only the rank had the proposal to raise his son conveyed to me. He doubtless did me a great deal of honor; but far from complaining about my refusal, he ought to congratulate himself on my discretion. If I had accepted his offer and my method were mistaken, the education would have been a failure. If I had succeeded, it would have been far worse. His son would have repudiated his title; he would no longer have wished to be a prince. I am too impressed by the greatness of a preceptor's duties, I feel my incapacity too much ever

16 Rousseau, Of the Social Contract, 98. Rousseau, Du contrat social, 110-111.

17 Rousseau, Of the Social Contract, 99. Rousseau, Du contrat social, 111.

18 See Michel Termolle, 'Rousseau, conseiller pédagogique par correspondance,' in Lire la correspondance de Rousseau, ed. Jacques Berchtold and Yannick Séité (Genève: Droz, 2007), Annales de la Société Jean-Jacques Rousseau 47, 309-326. See also John Christian Laursen, 'Télémaque manqué: Reverdil at Court in Copenhagen,' in Reconceptualizing Nature, Science, and Aesthetics: Contribution à une nouvelle approche des Lumières helvétiques, ed. Patrick Coleman, Anne Hofmann, and Simone Zurbuchen (Genève: Slatkine, 1998), 147-156. More generally about Denmark-Norway, see Henrik Horstboll, 'Defending Monarchism in Denmark-Norway in the Eighteenth Century', in Monarchisms in the Age of Enlightenment: Liberty, Patriotism, and the Common Good, ed. Hans Blom, John Christian Laursen, and Luisa Simonutti (Toronto, Buffalo, London: University of Toronto Press, 2007), 175-193. 
to accept such employment from whatever quarter it might be offered to me. $^{19}$

If Rousseau felt incapable of becoming a preceptor, it was because this function required him to comply with the established education practice and system of his time. Yet, Rousseau showed, in Emile, that the most important thing to learn could not be found in books on law or ethics, nor in a lecture room with a preceptor. Concerning Emile's education, he said, 'Living is the job I want to teach him. On leaving my hands, he will, I admit, be neither magistrate nor soldier nor priest. He will, in the first place, be a man'. ${ }^{20}$

If there was one thing that the education of princes did not provide, clearly it was the way to become a 'man'. Emile was raised in the countryside, not in a palace surrounded by the court and the army. If Rousseau felt incapable of accepting such employment, it was because he did not want to become a selfinterested author and he knew all too well that princes grew in an environment that would never allow them to become what they were supposed to be. He described the prince as a 'factitious being', corrupted by the court and the army as well as by the preceptor:

[A]fter having stifled his nature by passions that one has caused to be born in him - this factitious being is put in the hands of a preceptor who completes the development of the artificial seeds that he finds already all formed and teaches him everything, except to know himself, except to take advantage of himself, except to know how to live and to make himself happy. ${ }^{21}$

The result of such an education of princes was not long in coming and was the opposite of the result that should have been arrived at: 'The rich, the nobles, the kings are all children who, seeing that men are eager to relieve their misery, derive a puerile vanity from that very fact and are very proud of care that one would not give to them if they were grown men.22 For Rousseau, learning to be a citizen was not the principal task of education; first, children needed to learn how to become 'men'. On the one hand, they needed to be preserved and protected from a culture that corrupted them and, on the other, they needed to learn how to become free individuals. Authority was nothing without

\footnotetext{
19 Rousseau, Emile, or On Education, 176. Rousseau, Émile ou De l'éducation, 100.

$20 \quad$ Rousseau, Emile, or On Education, 166. Rousseau, Émile ou De l'éducation, 88.

21 Rousseau, Emile, or On Education, 174. Rousseau, Émile ou De l'éducation, 97.

22 Rousseau, Emile, or On Education, 216. Rousseau, Émile ou De l'éducation, 146-147.
} 
freedom and freedom was not the fate of the princes of this world because they would always need other people for everything. Princes were incapable of doing anything by themselves. The truth was that men brought up to rule were men brought up to be slaves; they always depended on others and because of this they were miserable. What could an education do to free a human being from such a deplorable condition? Even worse: what could an education do for the sake of a nation ruled by such a miserable being?

\section{2 \\ Teaching the Laws of Justice and Humanity: Burlamaqui's Royal Education}

In order to seek answers to these questions, we must leave Rousseau to one side and join the opposite camp. To Rousseau's question 'what can be expected of a succession of men brought up to rule?', Burlamaqui's response was that there was much that might be expected (or so at least he claimed to believe).

The portrait Rousseau painted of the philosophers and the literary establishment' he criticized could, in many respects, call to mind Burlamaqui's actions and works. Jean-Jacques Burlamaqui, born in Geneva just like Rousseau, was indeed a celebrated philosopher and jurist, who was professor of natural law and civil law at the Academy of Geneva (1723-1739), and achieved the greatest political honours as a member of the councils of his native republic. ${ }^{23}$ Frederick II, Landgrave of Hessen-Kassel (son of William VIII, nephew of the king of Sweden), came to Geneva in November 1732 and became Burlamaqui's pupil in his classes on the law of nature. In 1734, when the prince left the city, Burlamaqui accompanied him and followed him to his court in Kassel. ${ }^{24}$ The prince later came back to Geneva and stayed until 1737. During all this time, Burlamaqui was in charge of educating the young prince about the law of nature and the law of nations. When the two were not together, they continued their lessons by letter, with Burlamaqui sending exercises to the prince.

23 In a funeral oration given in the Sovereign Council of Geneva, the general prosecutor Leonard Buisson said, about Burlamaqui: 'Combien de lumières, en effet, combien de vertus n'avons-nous point vu briller dans Monsieur le Conseiller Burlamaqui! En lui se sont trouvés réunis l'homme de lettre, le philosophe, l'orateur, le jurisconsulte, l'homme d'État'. [What lights, indeed, what virtues have we not seen shine in Councillor Burlamaqui! In him were united the man of letters, the philosopher, the orator, the jurisconsult, the statesman]. Cited after Bernard Gagnebin, Burlamaqui et le droit naturel (Geneva: éditions de la Frégate, 1944), 78.

24 For an account of the particular circumstances in which the prince and Burlamaqui left Geneva, see Gagnebin, Burlamaqui et le droit naturel, 51-68. 
Without asserting that Burlamaqui was necessarily one of Rousseau's targets in the texts referred to above - even if Rousseau did mention Burlamaqui in his Second Discourse and otherwise critically engaged with his writings ${ }^{25}$ - it is difficult to avoid the impression that Burlamaqui matches Rousseau's description of the self-interested author in many respects. However, despite this resemblance, it is important to ask what exactly Burlamaqui's royal education consisted of and whether Rousseau's critique of the 'barbarous philosopher' could really apply to Burlamaqui's attempt to educate a young prince. ${ }^{26}$ I will also add that Rousseau's judgment was not entirely negative concerning all the professors in Geneva and Paris. He often pointed out that the main problem was the entire educational system rather than the educators. Maybe Burlamaqui was among those Rousseau had in mind when he said, "There are in the academy of Geneva and the University of Paris Professors whom I like, whom I esteem very much and believe to be very capable of instructing the Young well, if they were not forced to follow the established practice.'. ${ }^{27}$

What was the established practice in the case of Burlamaqui? Before answering this question, let us first explain how Burlamaqui defended the legitimacy of his royal education. To understand this, we need to focus on the role of the law of nature. Far from agreeing with the idea that royal education corrupted princes, Burlamaqui argued that this kind of education was absolutely necessary to the process of founding a good government, which would respect the law of nature and nations. In other words, Burlamaqui believed, or at least seemed to believe, that it was possible to raise an enlightened prince if the prince was educated according to the law of nature. This idea was directly linked to his definition of the law of nature and the law of nations as being fundamentally one and the same thing. Burlamaqui sided with Pufendorf and Barbeyrac by maintaining, in his Principles of Politic Law, that the law of nations

25 See for example Robert Derathé,Jean-Jacques Rousseau et la science politique de son temps (Paris: Vrin, 1971), and Gabriella Silvestrini, Diritto naturale e volontà generale. Il contrattualismo repubblicano di Jean-Jacques Rousseau (Torino: Claudiana, 2010), chap. 3.

26 Jean-Jacques Rousseau, 'Preface to the Discourse on the Origin and the Foundations of Inequality among Men,' in Rousseau, The Discourses and other early political writings, ed. Victor Gourevitch (Cambridge: Cambridge University Press, 1997), 125-26. French edition: Rousseau, Discours sur l'origine et les fondements de l'inégalité parmi les hommes (Paris: Gallimard, 1969), 54. Rousseau said: 'It is this ignorance of the nature of man that casts such uncertainty and obscurity on the genuine definition of natural right: for the idea of right, says M. Burlamaqui, and still more that of natural right, are manifestly ideas relative to the nature of man. Hence, he goes on, it is from this very nature of man, from his constitution and his state, that the principles of this science have to be deduced'.

Rousseau, Emile, or On Education, 165, note. Rousseau, Émile ou De l'éducation, 86, note. 
was 'no more than the laws of nature, which men, considered as members of society, in general, ought to practise towards each other.' ${ }^{28} \mathrm{He}$ said, in his Principles of Natural Law, that the law of nations was necessary 'to serve as a rule for mutual commerce' and that 'this law [could] be nothing else but the law of nature itself'. ${ }^{29}$

More precisely, Burlamaqui theorized the law of nations by dividing it into two types: first, the law of nations itself as universal, which was not different from the law of nature; second, the law of nations derived from conventions (between two or more states), which was obligatory only for the contracting states. However, the obligation linked to the second type of law of nations was the obligation of the law of nature itself (through the duty to respect our commitments). In other words, the law of nations could not be understood as a separate entity from the law of nature. One problem for Burlamaqui was that distinguishing the law of nations from the law of nature had very dangerous consequences, in particular in relation to princes:

It is owing perhaps to our distinguishing the law of nations from the law of nature, that we have insensibly accustomed ourselves to form quite a different judgment between the actions of sovereigns and those of private people. Nothing is more usual than to see men condemned in common, for things which we praise, or at least excuse in the persons of princes. ${ }^{30}$

The most fundamental point for Burlamaqui was to show that princes were not different from the common people in relation to the law of nature and that they were subject to the same obligations. If princes needed to learn one thing in their classroom, it was that 'there is only one sole and the same rule of justice for all mankind'. He carried on in the same passage: 'Princes who infringe the law of nations, commit as great a crime as private people, who violate the law of nature: and if there be any difference in the two cases, it must be charged to the prince's account, whose unjust actions are always attended with more dreadful consequences than those of private people'.

28 Jean-Jacques Burlamaqui, The Principles of Natural and Politic Law, ed. Petter Korkman (Indianapolis, IN: Liberty Fund, 2006), 288. French edition: Jean-Jacques Burlamaqui, Principes du droit politique (Amsterdam: Zacarie Chatelain, 1751), 2-3.

29 Burlamaqui, The Principles of Natural and Politic Law, 116. French edition: Burlamaqui, Principes du droit naturel (Genève: Barrillot \& Fils, 1747), 221.

30 Burlamaqui, The Principles of Natural and Politic Law, 118. Burlamaqui, Principes du droit naturel, 226-227. 
This refusal to distinguish between the law of nature and the law of nations grounded his definition of politics:

These remarks may serve to give us a just idea of that art, so necessary to the directors of states, and distinguished commonly by the name of Polity [Politics]. Polity [Politics] considered with regard to foreign states, is that ability and address by which a sovereign provides for the preservation, safety, prosperity and glory of the nation he governs, by respecting the laws of justice and humanity. ${ }^{31}$

The rules of the law of nature consisted of what reason approved and prescribed as the best means for attaining happiness. ${ }^{32}$ Nevertheless, reason had to be exercised and this is why education was so important. It was not a question of preserving and protecting children so they would learn to judge for themselves. It was a question of exercising and developing a faculty that would allow them to judge rightly or correctly. In brief, princes could only succeed in realizing good policies and could only understand what politics was if, and only if, they learned to respect 'the laws of justice and humanity'. What were these laws? They were nothing more than the laws of nature. The laws of nature were key to ensuring that the private interest of the prince and the public interest of his people were convergent. The role of the professor was clear: make sure that princes learned to govern on the basis of the law of nature. For Burlamaqui, the need for safety and security was not sufficient to ground the right of sovereignty. The right of sovereignty was justified insofar as it pursued public happiness. The role of the sovereign was to know the law of nature so she/he could promulgate positive laws on this basis. The sovereign was never 'the' law but only an interpreter of the law of nature and because she/he was an interpreter, it was better to be sure that her/his education gave her/him the necessary tools to interpret rightly. ${ }^{33}$

31 Burlamaqui, The Principles of Natural and Politic Law, 117. Burlamaqui, Principes du droit naturel, 222.

32 Burlamaqui, The Principles of Natural and Politic Law, 69. Burlamaqui, Principes du droit naturel, 58 .

33 See, for example, Jérémy Simonin, 'L'homme et le citoyen dans la science du droit naturel de J.-J. Burlamaqui,' in Genève et la Suisse dans la pensée politique, Actes du colloque de Genève (sept. 2006), ed. Michel Ganzin (Aix-en-Provence: Presses Universitaires d'Aix-Marseille, 2007), 89-101. For more on Burlamaqui's concept of sovereignty, see, for example, Gagnebin, Burlamaqui et le droit naturel, 183-189, 234-235, and Helena Rosenblatt, Rousseau and Geneva, From the First Discourse to the Social Contract, 17491762 (Cambridge: Cambridge University Press, 1997), 100-101. 
For Rousseau, the problem was always that the prince never became the virtuous person he was supposed to be and that royal education did not help him to improve. For Burlamaqui though, correct study of the law of nature had the capacity to turn the prince into a good and virtuous person and to achieve some results. In truth, man's nature consisted in exercising reason until he was able to know what the law of nature was. While Rousseau argued that learning too much about the science of reigning made princes ignorant of it, the point for Burlamaqui was to show that princes needed to stay in the classroom as long as necessary for them to learn the law of nature, because all their actions depended on their knowledge of the law of nature, on the battlefield as well as everywhere else.

In Burlamaqui's teaching on the law of nature, there was, for example, the idea that the strength of a state, with regard to war, was its people and that the prince had 'to neglect nothing that [could] either support or augment the number of them. ${ }^{34}$ It was one of the main teachings of the law of nature to show the prince the importance of his people. Another important lesson was related to the prince's training in relation to obedience. The written correspondence between Prince Frederick of Hessen-Kassel and Burlamaqui provides a better understanding of Burlamaqui's method for teaching the law of nature to the prince correctly. ${ }^{35}$ One of the letters explained, for example, how the prince should study the law of nature when the professor was not with him (29 May 1734, Burlamaqui to Frederick):

Have Mr. Schmerfeld come to your study at 9 o'clock. Settle him in the armchair beside your desk, then take your second ledger and continue to peruse from the place where you left off the day before yesterday. After that, give your paper to Mr. Schmerfeld who will question you. Repeat this little exercise until 10 o'clock strikes and I will vouch for the success of my method.

Burlamaqui concluded in this letter: 'Sir, I give you frankly the whole secret of my art and should you make sustained use of it, you will soon be in a position to oust me'. At first, the study of the law of nature, at least when Burlamaqui was not with the prince, did not seem to be too demanding and to take too

34 Burlamaqui, The Principles of Natural and Politic Law, 291. Burlamaqui, Principes du droit politique, 10.

35 Correspondence between Burlamaqui and Frederick of Hessen-Kassel, archival material from Staatsarchiv Marburg, replica accessed in Geneva Library, Facs 37, f. 90-142 (my translation). 
much of the prince's time. However, as the prince grew up, it appears that he had to spend more and more time in the study room so he could understand all the implications of the law of nature for his future career.

A letter dated 19th December 1735, from Burlamaqui to Frederick, was an exercise to test the prince's ability to respond to the question of the usefulness of his education. In this letter, Burlamaqui asked the prince if those who were destined to rule should receive the same education as those destined to obey. Burlamaqui began by explaining the interest of such exercises to the prince:

That is to say, Sir, that all one may have learnt in the study room and beneath the eyes and the direction of a master is nothing if one does not then try to make use of it one's self [...]; your mind will work, you will set in motion your energy and your talents, you will train yourself in consistent and sustained attention, which is more necessary to people of your standing than any other.

Burlamaqui then asked the prince:

In a word, I ask whether it is just and fitting to subject those who are born to rule to the same schooling as those who are destined to obey and whether a little common sense and some slight knowledge of the sciences does not suffice a prince for his glory and his happiness, provided that he learns early to know the world and, above all, that he is trained in the great art of war.

As we can guess, the answer was 'no'. A little common sense and some slight knowledge of the sciences were not sufficient for princes. Princes needed to study the law of nature if they wanted to reign justly and rightly. Experience was not enough. Knowledge, exercise and attention were the key to success.

It was part of the prince's training to be able to explain clearly the reasons why the law of nature was so important. Thus, Frederick accomplished the exercise and answered Burlamaqui's question by repeating Burlamaqui's lessons. Frederick began by pointing out that public happiness was the aim of politics and that it was by studying the law of nature that princes had the opportunity of realizing this aim. The prince ended with a reminder of the importance of leaving future governors in the study room, cut off from the world, until they learned what they needed to know ('Answer to the First Letter' by Frederick):

A prince, for example, who must one day be called to govern peoples, is naturally obliged to have as his principal object the happiness of his 
people and from this it follows that the means apt to lead him to this end must be his principal occupation: enlightening his mind through knowledge and shaping his heart through sustained attention; these are certainly the only means that might lead him there.

The prince carried on:

It is certain that neither the world nor the court nor the army can be the primary educator of a young prince. The flattery of one side and the dissipation and frequent opportunities to succumb to his passions of the other are too dangerous for a young man to be exposed to them. Still less would he be able to draw from them the knowledge that is necessary and suitable for the position he must occupy. Therefore, a young prince should be left in the study room until he is instructed in all that he must know.

Rousseau and Burlamaqui might agree on the idea that the court and the army were dangerous for a prince. The only difference was that Burlamaqui thought books could preserve and protect his student from bad influence whereas Rousseau thought that books were themselves part of the bad influence the prince needed to be preserved from.

Following Burlamaqui's teaching, Frederick explained why he could not learn what he needed to know in the court or in the army and why he should be 'left in the study room' to be instructed by books instead of being instructed by the real world outside the classroom. He pointed out something important that he had been taught, namely that the virtues of war were not different from the virtues of justice and humanity. This confirms the connection Burlamaqui made between the law of nature and the law of nations. Prince Frederick had learned to condemn the consequences of war and knew the importance of learning to obey before learning to command. He concluded:

The virtues of war cannot dispense with justice, moderation, and humanity, which differs only by its application. Nonetheless, one cannot deny that peace is more advantageous a situation than war, whose unfortunate consequences are only too well known. In answer to your final question, I end by saying that he who cannot obey will never be able to rule well.

Even if Rousseau was sceptical about the benefit of a prince being left in the study room', he seemed to agree with Burlamaqui on the idea that learning obedience was one of the keys to a good royal education and that the consequences of war were a disaster that needed to be avoided as far as possible. In 
truth, there is apparent agreement between them on many points concerning the definition of what made a good basis for a successful royal education, but the major difference was that Rousseau thought it was not possible to succeed in this task, while Burlamaqui thought it was.

It might be thought that Rousseau's pessimism and Burlamaqui's optimism concerning royal education also depended on their personal situations. Burlamaqui clearly belonged to the literary establishment' of his time, with all the honours that came with that position. He was a politician and committed professor who was concerned about what could be done here and now, in the nonideal situation of Europe at that time; he certainly had a pragmatic sensibility, which made him act in favour of princes, monarchs, and governments in power because it seemed to him that this was likely to give better results. ${ }^{36}$ Yet it is also true that Burlamaqui, just like Barbeyrac, was not particularly in favour of absolute monarchy. He clearly preferred a 'tempered government' with a mix of democratic and aristocratic elements. ${ }^{37}$ Burlamaqui was more optimistic than Rousseau, because he had better opportunities, giving him more reason to believe that his actions could have an impact in politics. He was, after all, directly in charge of a prince's education and this function offered the prospect of great influence. But was it truly the case? Did the Burlamaquian education eventually bear fruit?

It seems that only history can have the final word and be the judge of who was right, Rousseau or Burlamaqui, about the education of princes. Of course, most historical examples show that it is difficult to prove Rousseau wrong in his radical critique of royal education. At the same time, it may well be argued that princes could have been far worse without professors like Burlamaqui who tried to teach them the law of nature. We can at least credit Burlamaqui with the merit of having tried and we can analyse the results of his teachings to see if we can find a specimen of what we could call a Burlamaquian enlightened prince.

$3^{6}$ For an account of Burlamaqui's role in politics, especially in relation to the troubles of 1734 in Geneva, see Gagnebin, Burlamaqui et le droit naturel, 51-69. It appears that Burlamaqui preferred giving more support to the aristocracy in power than to the bourgeoisie.

37 Rosenblatt, Rousseau and Geneva, From the First Discourse to the Social Contract, 1749-1762, 100. 
I will let the reader judge for her/himself and I will give only two potential candidates for the title of Burlamaquian enlightened prince, two examples that may provide an illustration of a prince educated on the law of nature. I am aware that the question 'what is enlightened absolutism?' is far from being resolved today and it is not my aim to try to answer it. ${ }^{38} \mathrm{I}$ agree with Charles W. Ingrao when he explains, 'it is difficult to avoid the conclusion that the task of reaching a consensus had been complicated by an underlying clash of national cultural and historical perspectives. ${ }^{39}$ I only propose here to look at two figures that might help us to determine how to consider the efficiency of Burlamaqui's royal education on the law of nature when it comes to practice.

For the first example, I return to Prince Frederick of Hessen-Kassel, since we know that he directly benefited from Burlamaqui's teaching. Even if Frederick seemed to learn Burlamaqui's lessons on the law of nature correctly, it is not certain that he could avoid Rousseau's criticisms concerning the efficiency of his royal education. It is certainly one thing to learn correctly, but quite another to apply what was taught. My second example is Gustav III of Sweden because, even if Burlamaqui was not directly his professor, Gustav was educated using Burlamaqui's writings and he is certainly often acknowledged today for being one of the figures of the eighteenth-century monarchic enlightenment.

First, Frederick of Hessen-Kassel. Of course, it is important to mention that Burlamaqui was not the only one in charge of the prince's education. There were others: for example, Jean-Pierre de Crousaz, former professor of philosophy at the Academy of Lausanne, also had this task for a while. In any case, Prince Frederick grew up with the teachings of Burlamaqui's law of nature and he was indeed known for being an enlightened monarch with respect to arts and letters. He admired the philosophers, for example Voltaire, and enjoyed writing some philosophical thoughts himself. The prince was well known for having enhanced the city of Kassel and its residential properties and he contributed to the development of Marburg University. However, his reputation in other areas was more debatable. He was also very famous for his mercenaries and he raised money by renting his soldiers out many times to those engaged in conflicts, including the American War of Independence, where he

38 As Tore Frängsmyr noted concerning the term 'Enlightenment', 'Originally, the designation was used mainly for the French Enlightenment but it has since come to be used for rationalist currents of ideas of all possible types or as a purely chronological label'. 'Defining the Enlightenment: The Swedish Case,' in Centre(s) and Margins, Enlightenment from Belfast to Beijing, ed. Marie-Christine Skuncke (Paris: Honoré Champion, 2003), 196. 
sent troops to support Great Britain. If Frederick was a Burlamaquian enlightened prince, he was one of a warlike kind. Ingrao commented: 'Notwithstanding everything that he imbibed from the Enlightenment's teaching of natural law, it was inevitable that Frederick would derive a more sanguine attitude toward the military and warfare. [...] Like all Hessian princes he was trained to be a soldier. ${ }^{40}$ Because of this mixture of Enlightenment with military temper, it is not certain that Frederick would have fulfilled Rousseau's criteria or would have gained his approval.

Second, let us consider Gustav III of Sweden as another example of an eighteenth-century prince educated with Burlamaqui's books on law and ethics. Gustav was born in 1746 and ruled between 1771 and 1792. In 1756, Count Carl Fredrik Scheffer, well known in the philosophical circles of Paris, became the prince's new governor and educated him in contemporary political theory, with an emphasis on the works of Locke, Wolff, and Burlamaqui. ${ }^{41}$ In his instructions to the prince's preceptor in 1757 , Scheffer explained that once the prince had gained clear and accurate notions of his duties as a 'man', he needed to learn in an orderly and systematic way what were his duties as a member of civil society. Scheffer thought that Burlamaqui's work was appropriate as Gustav's manual because it was a short but solid system of the law of nature and nations. He thought it was also the most convincing work in terms of proving that unlimited despotism was as dangerous for the prince as it was for the prince's subjects and that the best government for all was grounded on political freedom and demarcated by fundamental laws. ${ }^{42}$ As Marie-Christine

\footnotetext{
40 Ingrao, The Hessian Mercenary State, 15.

41 Pièces concernant l'éducation du prince royal, à présent roi de Suède par son excellence $\mathrm{Mr}$ le Comte Charles de Scheffer, sénateur du royaume et commandeur des ordres du roi, \&c., traduites du suédois (Stockholm: H. Fougt, 1773), 5-6: 'pour parvenir à donner à S.A.R des idées claires et évidentes des vertus et des vices, il est important qu'on lui fasse connaître quelque ouvrage qui traite la morale systématiquement. À cet effet je recommande à Mr le Conseiller de faire étudier à S.A.R l'extrait que j'ai tiré des ouvrages de Wolff, de Locke, de Burlamaqui et d'autres'. [In order to succeed in giving HRH clear and evident ideas on virtues and vices, it is important that he is given to study some work that treats of morality systematically. With this in mind, I recommend that the Councillor has HRH study the extract I have taken from the works of Wolff, Locke, Burlamaqui and others], my translation.

42 Pièces concernant l'éducation du prince royal, 6-7: 'Un système court mais solide du droit de la nature et des gens, qui depuis quelques années a été publié à Genève, peut servir à Mr le conseiller pour ce genre d'instruction, et je recommande d'autant plus volontiers ce petit ouvrage, qu'il est de tous ceux que je connais sur ce sujet, celui qui prouve d'une manière plus convaincante, que le despotisme illimité est aussi dangereux pour le prince, que pour les sujets ; qu'au contraire la liberté politique, et une puissance royale bornée par des lois fondamentales, étant plus conformes à la loi naturelle, constituent aussi le
} 
Skuncke explains, limited monarchy appeared to be the best form of government in accordance with the law of nature. ${ }^{43}$ Just like Frederick, Gustav had to spend most of his days in the lecture room and Scheffer prescribed that the prince had first to study the law of nature and nations before he could study Swedish public law. ${ }^{44}$

Hildor Arnold Barton underlines the fact that catalogues in the Royal Library in Stockholm showed that Gustav's personal library was voluminous and that he quickly acquired the latest works of the Enlightenment. ${ }^{45}$ Gustav was fond of theatre and wrote some pieces himself. He met various philosophers in Paris, including Helvetius, Marmontel, Grimm, Quesnay, d'Alembert, and the elder Mirabeau. He also visited Rousseau and, even if Gustav seemed to prefer Voltaire's ideas to Rousseau's critique of sciences and arts and to the Social Contract, ${ }^{46}$ Barton also evokes Gustav's 'undeniable fascination' with Rousseau. ${ }^{47}$ Burlamaqui's work also seemed to have a place of honour in the prince's Order of the Arc. ${ }^{48}$

gouvernement le plus glorieux pour les rois, et le plus avantageux pour les hommes en général'. [A short but solid system on the law of nature and nations, published some years ago in Geneva, might serve the Councillor for this type of instruction and I recommend wholeheartedly this short work which is, of all those I know on this subject, that which proves most convincingly that unlimited despotism is as dangerous for the prince as for his subjects, that, on the contrary, political liberty and a royal power limited by fundamental laws, conforming more closely to the law of nature, constitute the most glorious form of government for kings and the most advantageous for men in general].

43 Marie-Christine Skuncke, 'Un prince suédois auteur français: l'éducation de Gustave III, 1756-1762,' Studies on Voltaire \& the Eighteenth Century 296 (1992), 127.

44 Pièces concernant l'éducation du prince royal, 12: 'chaque jour de la semaine, excepté le dimanche, depuis dix heures du matin jusqu'à une heure après midi, et depuis trois heures du soir jusqu'à six' and 'lorsque S.A.R aura fait assez de progrès dans le droit public universel et le droit des gens pour qu'on puisse commencer son instruction dans le droit public de la patrie, c'est-à-dire, dans les lois fondamentales de la Suède, on communiquera à Mr le conseiller une instruction particulière sur ce sujet délicat'. [Every day of the week, Sunday excepted, from ten in the morning until one in the afternoon and from three in the afternoon until six] and [when HRH has made sufficient progress in universal public law and the law of the people for his instruction to be begun in the country's public law, that is, the fundamental laws of Sweden, particular instruction on this delicate subject will be sent to the Councillor].

45 Hildor Arnold Barton, Essays on Scandinavian History (Carbondale: Southern Illinois University Press, 2008), 17.

46 Barton, Essays on Scandinavian History, 19.

47 Ibid., 37.

48 Skuncke, 'Un prince suédois auteur français: l'éducation de Gustave III, 1756-1762,' 148-153. 
That said, the question 'Was Gustav a tyrant or an enlightened prince?' is still subject to debate. During Gustav's life, his contemporaries' opinions were already divergent on this question. Skuncke points out that Gustav was one of the most controversial kings of Sweden. She also describes the tensions around Gustav's education, between his mother, partisan of absolutism, and his educators, assigned with the charge of teaching him that the present system of government in Sweden was the best possible. ${ }^{49}$ Even though Claude Nordmann underlines the ambiguity of Gustav and the complexity of judging of his actions during his reign, he mentions at the same time that he was unquestionably 'one of the most brilliant personalities of the rich eighteenth century'.50 Gustav was, according to him, 'a model of the enlightened absolutist', 'idealist', 'liberal by inclination,' 'a Caesarean democrat who conducted a domestic policy of orders', 'levelling, seeking equality for everyone, but following tortuous paths. ${ }^{51} \mathrm{He}$ was also a patron of the arts and letters and allowed his country to fully participate in the Enlightenment. The published correspondence between Scheffer and Gustav helped to spread the image of an enlightened monarch across Europe. ${ }^{52}$

The assessment of his reign is, however, complex and I will not try to provide an overview here. I will simply go on with another of Nordmann's observations, that Gustav was a committed person, engaged in the intellectual movement of his time, open-minded, but that he was also the victim of a real 'disequilibrium between his ambitions and his possibilities..$^{53}$ Gustav was the one responsible for a law that progressively restricted the freedom of the press (1774) but he was also the one who engaged in social egalitarian reforms (1789) and he was finally murdered.

Two important limitations that bring into question the unmitigated success of Burlamaqui's education can be inspired respectively by Ingrao's work on Frederick and the Pieces Concerning the Education of the Royal Prince with Scheffer's instructions for educating Gustav. These limitations may justify a belief that Rousseau could have been wrong when he stated that 'a royal education necessarily corrupts those who receive it' because neither Frederick nor Gustav

49 Skuncke, 'Un prince suédois auteur français: l'éducation de Gustave III, 1756-1762,' $125^{-137 .}$

$50 \quad$ Claude Nordmann, Gustave III Un démocrate couronné (Lille: Presses Universitaires du Septentrion, 1986), 1, my translation.

$5^{1} \quad$ Nordmann, Gustave III Un démocrate couronné, 265.

52 Skuncke, 'Un prince suédois auteur français: l'éducation de Gustave III, 1756-1762,' 157-158.

53 Nordmann, Gustave III Un démocrate couronné, 1. 
seemed to have been corrupted by their Burlamaquian education. At the same time, Burlamaqui could have been wrong for having been too confident in the possibilities of an education based on the law of nature, which was surely not enough to produce either a good prince or a good government. So Burlamaquian education may have been partly successful but some other elements may have prevented it really bearing fruit. Ingrao points out, for example:

$[\mathrm{T}]$ he Frederician regime was obliged to contend with preexisting structures that were essentially inimical to the thrust of its programs: unfavorable demographic and economic circumstances, entrenched institutions that enjoyed lives and constituencies of their own, and existing philosophies of government not wholly compatible with the new ideas of government reformers. ${ }^{54}$

In truth, this difficulty had already been pointed out by Rousseau, who had noticed that the system and the established practice were the core of the problem, even when the preceptor was not corrupt (or at least when he was not entirely corrupt). The prince was not the sole element in need of education the role of bureaucracy was important and the government always functioned by consensus.

So, if we allow that Burlamaqui was successful in his attempt to educate Prince Frederick using the law of nature, that was still no guarantee of successful reforms for the government because the prince, even the absolutist prince, was just an element of the system - the other parts had not all been educated using the law of nature. However, this fact did not prevent Ingrao from gathering sufficient quantitative evidence to support the idea that 'despite its limits, failures, and costs, the Frederician regime succeeded in improving the quality of life of most Hessians.' 55 This means that some seeds of Burlamaquian Enlightenment may have given good results in this case.

The Pieces underlined another difficulty that could hinder a prince's education. Scheffer emphasized the importance of the condition of the prince himself, because reforms could not be undertaken if the prince was not heard, nor loved, nor respected by his subjects. He explained:

If Mgr the prince royal, as there is every reason to presume, makes great progress in all the areas of science just mentioned, he will certainly be a

54 Ingrao, The Hessian Mercenary State, 11.
55 Ibid., 209. 
very enlightened and highly educated prince, but that is not what makes the king's happiness, nor what makes him worthy of his people's love. That requires more feeling than reason; it requires a high and noble soul, a gentle character, a heart filled with benevolence and love for men. To provide the young prince these great benefits, we must, while cultivating his reason, pay constant attention to his heart and his personality and conduct, as far as possible, all his studies in such a way that his heart might be touched, purified, imbued with desire for the love, esteem, and attachment of men. ${ }^{56}$

Reason without feeling or more reason than feeling - perhaps in this lay one major difficulty that could not be solved by a Burlamaquian education based on the law of nature alone. In Emile, Rousseau pointed out what appeared to him as a weakness of the law of nature, at least the law of nature as it was taught in his time. He said that 'the entire right of Nature is only a chimera if it is not founded on a natural need in the human heart'. As for the law of nature, it had to be based on feeling: 'From this I conclude that it is not true that the precepts of natural law are founded on reason alone. They have a base more solid and sure. Love of men derived from love of self is the principle of human justice. ${ }^{57}$ However, this principle of human justice was not to be found directly in books. Even less was it to be found in philosophers' books, because they judged others by themselves and gave a wrong description of humanity. Reading books was not the best way to feel love for men and benevolence. Only a natural feeling such as love of self could lead the way, if it was not too far perverted by education.

This difficulty was clearly linked to the point made by Rousseau above, namely that princes needed to learn how to become 'men'. This was even more important if it was connected to the importance of deserving the love

$5^{6}$ Pièces concernant l'éducation du prince royal, 13-14: 'Si Mgr le prince royal, comme on a tout lieu de le présumer, fait de grands progrès dans toutes les parties des sciences qu'on vient d'énoncer, il sera certainement un prince très éclairé et très instruit ; mais ce n'est pas là ce qui fait le bonheur d'un roi, ni ce qui le rend digne de l'amour de son peuple. Il faut pour cela plus de sentiment que d'esprit ; il faut une âme noble et élevée, un caractère doux, un cœur rempli de bienfaisance et d'amour pour les hommes. Pour procurer au jeune prince ces grands avantages, on doit, en cultivant son esprit, porter une attention continuelle sur son cœur et sur son caractère et diriger autant qu'il est possible toutes ses études de manière que le cœur puisse être touché, épuré, pénétré du désir d'obtenir l'amour, l'estime et l'attachement des hommes'.

57 Rousseau, Emile or on Education, 389, text and note. Rousseau, Émile ou De l'éducation, 359 , text and note. 
of the people. A prince could not be followed if his people did not love him and the prince could not deserve the love of his people if he was incapable of benevolence and love of men. The process of the prince's identification with the rest of humanity was only possible if the prince did not stay cut off from the rest of the world. Too many books, too many hours spent in the classroom, and eventually no one on the battlefield to look around and to repeat after Rousseau, 'Pity, indignation swell up in the depths of my heart!' And what was more natural than pity and indignation in the face of the reality of the world? It seemed that experience could teach what scholars and jurisconsults could never demonstrate in a lecture room. But people living in the real world had no choice but to face reality and, surely, a prince who could not face reality with his people could never be loved and respected. Princes incapable of feeling pity and indignation, incapable of benevolence and love of men were neither lovable nor respectable. People needed to love and to respect a 'man' before they could love and respect a prince.

Burlamaqui did not make the distinction between educating someone to become a 'man' and educating someone to become a citizen. Maybe it was because Burlamaqui did not believe that it was part of his role to do so or, more likely, he did not agree with Rousseau's idea that the major role of education was to make a child become a 'man'. Childhood for Rousseau was the moment of life to open up to the world and to others. If this opportunity was missed, it could be lost forever. Clearly, there is a deeper disagreement here between the two philosophers about what was human nature and what was its perfectibility. In any case, it appears that Scheffer tried to combine a Burlamaquian education and a Rousseauist one when he wrote his instructions to the prince's preceptor - he wanted to educate Gustav to become both a 'man' and a prince, assuming that was compatible. Maybe it was, despite what Rousseau claimed. But then it was entirely in the hands of the preceptor to succeed in this task certainly a heavy burden for a person.

\section{Bibliography}

Barton, Arnold H., Essays on Scandinavian History (Carbondale: Southern Illinois University Press, 2008).

Burlamaqui, Jean-Jacques, Principes du droit naturel (Genève: Barrillot \& Fils, 1747).

Burlamaqui, Jean-Jacques, Principes du droit politique (Amsterdam: Zacarie Chatelain, 1751).

Burlamaqui, Jean-Jacques, The Principles of Natural and Politic Law, transl. Thomas Nugent, ed. Petter Korkman (Indianapolis, IN: Liberty fund, 20o6). 
Correspondence between Burlamaqui and Frederick of Hessen-Kassel, archival material from Staatsarchiv Marburg, replica accessible in Geneva Library, Facs 37, f. 90-142.

Derathé, Robert, Jean-Jacques Rousseau et la science politique de son temps (Paris: Vrin, 1971).

Fénelon, Les aventures de Télémaque (Paris: Garnier, 1987).

Fénelon, Telemachus, son of Ulysses, ed. and transl. Patrick Riley (Cambridge: Cambridge University Press, 1994).

Frängsmyr, Tore, 'Defining the Enlightenment: The Swedish Case,' in Centre(s) and Margins. Enlightenment from Belfast to Beijing, ed. Marie-Christine Skuncke (Paris: Honoré Champion, 2003), 195-212.

Gagnebin, Bernard, Burlamaqui et le droit naturel (Genève: éditions de la Frégate, 1944). Hobbes, Thomas, Leviathan, ed. Richard Tuck (Cambridge: Cambridge University Press, 1996).

Horstboll, Henrik, 'Defending Monarchism in Denmark-Norway in the Eighteenth Century,' in Monarchisms in the Age of Enlightenment: Liberty, Patriotism, and the Common Good, ed. Hans Blom, John Christian Laursen, and Luisa Simonutti (Toronto, Buffalo, London: University of Toronto Press, 2007), 175-193.

Ingrao, Charles W., The Hessian Mercenary State: Ideas, Institutions, and Reform under Frederick II, 1760-1785 (Cambridge: Cambridge University Press, 1987).

Laursen, John C., 'Télémaque manqué: Reverdil at Court in Copenhagen,' in Reconceptualizing Nature, Science, and Aesthetics: Contribution à une nouvelle approche des Lumières helvétiques, ed. Patrick Coleman, Anne Hofmann, and Simone Zurbuchen (Genève: Slatkine, 1998), 147-156.

Nordmann, Claude, Gustave III, un démocrate couronné (Lille: Presses Universitaires du Septentrion, 1986).

Pièces concernant l'éducation du prince royal, à présent roi de Suède par son excellence Mr le Comte Charles de Scheffer, sénateur du royaume et commandeur des ordres du roi, \&c., traduites du suédois (Stockholm: H. Fougt, 1773).

Rosenblatt, Helena, Rousseau and Geneva. From the First Discourse to the Social Contract, 1749-1762 (Cambridge: Cambridge University Press, 1997).

Rousseau, Jean-Jacques, Émile ou De l'éducation (Paris: Gallimard, 1969).

Rousseau, Jean-Jacques, Discours sur l'origine et les fondements de l'inégalité parmi les hommes (Paris: Gallimard, 1969).

Rousseau, Jean-Jacques, The Social Contract and other later political writings, transl. and ed. Victor Gourevitch (Cambridge: Cambridge University Press, 1997).

Rousseau, Jean-Jacques. The Discourses and other early political writings, transl. and ed. Victor Gourevitch (Cambridge: Cambridge University Press, 1997).

Rousseau, Jean-Jacques, Du contrat social (Paris: Flammarion, 2001).

Rousseau, Jean-Jacques, Principes du droit de la guerre. Écrits sur la paix perpétuelle, ed. Blaise Bachofen and Céline Spector (Paris: Vrin, 2008). 
Rousseau, Jean-Jacques, Emile or on Education, transl. and ed. Christopher Kelly and Allan Bloom (Hanover and London: University Press of New England, 2010).

Silvestrini, Gabriella, Diritto naturale e volontà generale. Il contrattualismo repubblicano diJean-Jacques Rousseau (Torino: Claudiana, 2010).

Simonin, Jérémy, 'L'homme et le citoyen dans la science du droit naturel de J.-J. Burlamaqui,' in Genève et la Suisse dans la pensée politique, Actes du colloque de Genève (sept. 2006), ed. Michel Ganzin (Aix-en-Provence: Presses Universitaires d'AixMarseille, 2007), 89-101.

Skuncke, Marie-Christine, 'Un prince suédois auteur français: l'éducation de Gustave III, 1756-1762,' Studies on Voltaire \& the Eighteenth Century 296 (1992), 123-163.

Termolle, Michel, 'Rousseau, conseiller pédagogique par correspondance,' in Lire la correspondance de Rousseau, ed. Jacques Berchtold and Yannick Séité (Genève: Droz, 2007), Annales de la Société Jean-Jacques Rousseau 47, 309-326. 